\title{
Two conceptions of international practice: Aristotelian praxis or Wittgensteinian language-games?
}

\author{
MERVYN FROST AND SILVIYA LECHNER
}

\begin{abstract}
Scholars from the recent 'practice turn' in International Relations have urged us to rethink the international realm in terms of practices. The principal exponents of the turn, Emanuel Adler and Vincent Pouliot, have refurbished Pierre Bourdieu's theory of practice to produce their own account of international practices. In a review of the practice turn, Chris Brown has argued that Bourdieu's notion of practice shares basic affinities with Aristotle's concept of praxis. While practice turn scholars may not adhere to a rigid canon of thought, they seem to share an Aristotelian conception of praxis. This reading of the turn to practice, though plausible, captures one part of the story. The central thesis of the present article is that instead of one there are two, distinctive conceptions of practice - Aristotelian and Wittgensteinian - and therefore two distinctive ways in which the character of international practices might be understood. More concretely, the aim is to show that the conception of international practices, rooted in Wittgenstein's view of practices as language-games, can be particularly illuminating to all those who seek to understand international relations.
\end{abstract}

Mervyn Frost is Professor of International Relations in the Department of War Studies, King's College, London and Senior Research Associate in the Department of Politics and International Relations, University of Johannesburg. His research focuses on ethics in international relations. His single authored monographs include: Towards a Normative Theory of International Relations (Cambridge University Press, 1986); Ethics in International Relations (Cambridge University Press, 1996); Constituting Human Rights: Global Civil Society and the Society of Democratic States (Routledge, 2002); and Global Ethics: Anarchy, Freedom and International Relations (Routledge, 2009). He edited International Ethics (4 vols, Sage 2011).

Silviya Lechner was Lecturer, and is currently visiting Research Fellow, in the Department of War Studies, King's College London. She specialises in political philosophy, philosophy of action, and international ethics, and has published on Oakeshott, humanitarian intervention, the theory of international law, and enhancement in bioethics. She is currently writing a book on Hobbes's conception of rights.

\section{Introduction}

The arrival of the 'practice turn' in the field of International Relations (IR) has promised a fresh way of thinking about a host of issues that confront us, as observers and participants, in international affairs. ${ }^{1}$ Its proponents urge that a more complete

\footnotetext{
${ }^{1}$ Key sources for the current Bourdieu-inspired practice turn in IR include: Emanuel Adler and Vincent Pouliot, 'International practices', International Theory, 3:1 (2011), pp. 1-36; Adler and Pouliot (eds), International Practices (New York: Cambridge University Press, 2011); Pouliot, International Security in Practice: The Politics of NATO-Russia Diplomacy (New York: Cambridge University Press, 2010); and Peter Jackson, 'Pierre Bourdieu, the "cultural turn" and the practice of international history', Review of
} 
understanding of international relations would be achieved if we adopt international practices as a central concept of analysis. But what do terms like 'practices' or 'international practices' mean? The answer, according to Emanuel Adler and Vincent Pouliot, the currently leading proponents of this view, is to be found by reworking the 'theory of practice' of French sociologist Pierre Bourdieu. ${ }^{2}$ In an important article that assesses the contribution of the practice turn in IR, ${ }^{3}$ Chris Brown has identified affinities between Bourdieu's notion of practice and 'praxis' -Aristotle's term for action (meaningful doing). ${ }^{4}$ Brown concludes that while scholars from the practice turn may not adhere to a rigid canon of thought, they seem to share an Aristotelian conception of praxis. Essentially, then, practice is praxis. This reading, though plausible, is partial at best. What has been left out is the significantly different conception of practice developed by Ludwig Wittgenstein. ${ }^{5}$ The central thesis of this article is that instead of one there are two conceptions of practice - an Aristotelian and a Wittgensteinian. Our primary task is to show that these two conceptions are indeed distinct and distinctive, and that they translate into two distinctive ways of understanding international practice. Yet, distinctiveness is not incommensurability both conceptions are situated within a shared discourse of intelligent human conduct. Distinctiveness presents a weaker or softer criterion of comparing objects or theories than incommensurability, which does not presuppose a shared universe of discourse. In a recent study, Erik Ringmar has criticised proponents of the practice turn in IR for their misguided attempt to fabricate a universal, inter-paradigm language of practice that ignores the problem of incommensurability of theoretical languages. ${ }^{6}$ What we wish to show instead is that Aristotle's and Wittgenstein's views of practice, even though distinct, are not incommensurable. Certain theorists - including IR constructivists - might soften the proposed contrast even further, by emphasising that both views converge in the notion of meaning as socially constituted. ${ }^{7}$ But here we

International Studies, 34:1 (2008), pp. 155-81. See also Oliver Kessler and Xavier Guillaume, 'Everyday practices of International Relations: People in organizations', Journal of International Relations and Development, 15:1 (2012), pp. 110-20; and Christian Bueger and Frank Gadinger, International Practice Theory: New Perspectives (Basingstoke: Palgrave, 2014). A return of practice to the linguistic turn has been proposed by Iver B. Neumann, 'Returning practice to the linguistic turn: the case of diplomacy', Millennium: Journal of International Studies, 31:3 (2002), pp. 627-51; Nicholas Onuf, World of Our Making: Rules and Rule in Social Theory and International Relations (Columbia, SC: University of South Carolina Press, 1989); Onuf, 'Polemics: Fitting metaphors - the case of the European Union', Perspectives, 18:1 (2010), pp. 63-76.

2 See fn. 1. Bourdieu's theory of practice is articulated in Pierre Bourdieu, Outline of a Theory of Practice, trans. Richard Nice (Cambridge: Cambridge University Press, 1977 [orig. pub. 1972]); and Bourdieu, The Logic of Practice, trans. Richard Nice (Stanford: Stanford University Press, 1990 [orig. pub. 1980]).

${ }^{3}$ Chris Brown, 'The "practice turn", phronesis and classical realism: Towards a phronetic international political theory?', Millennium: Journal of International Studies, 40:3 (2012), pp. 439-56.

4 In the ensuing discussion, 'praxis' refers to Aristotle's praxis (to be discussed in Section Two below). Typically, the term action implies that an agent brings about a change in the external world. Aristotle's notion of action (praxis) however is stronger (in a philosophical sense) because it implies an additional premise: that the change is supposed to evoke a meaningful response from an audience.

5 The key text is Ludwig Wittgenstein, Philosophical Investigations, trans. G. E. M. Anscombe (Oxford: Blackwell, 1953) - henceforth abbreviated as ' $P P$ '. References are given by paragraph number ( $)$ ).

6 Erik Ringmar, 'The search for dialogue as a hindrance to understanding: Practices as inter-paradigmatic research program', International Theory, 1:6 (2014), pp. 1-27. The 'practice turn' that Ringmar criticises is represented by the essays in Adler and Pouliot's edited volume International Practices.

${ }^{7}$ Since Aristotle's and Wittgenstein's views of action are distinguished within the shared discourse of action as meaningful doing, some theorists might focus on this shared component by examining the intersubjectively constituted meaning of action as such without distinguishing it, as we do here, from the intersubjectively constituted meaning of practices-dependent action. Constructivists within IR are likely to be open to this enterprise. See Friedrich V. Kratochwil, 'Constructivism as an approach to interdisciplinary study', in Karin M. Fierke and Knud Erik Jørgensen (eds), Constructing International 
have chosen the path of conceptual differentiation. Our concrete task thus is to draw attention to the Wittgensteinian perspective which itself relies on the principle of differentiation. As we shall see, the general realm of practice for Wittgenstein is differentiated into quasi-autonomous domains: practices or 'language-games', as he brands them. ${ }^{8}$

It should be noted at the outset that we do not seek to recommend a particular reading of Aristotle's or Wittgenstein's ideas as the singularly correct one, nor do we propose to evaluate the reception of these ideas within IR discourse. ${ }^{9}$ Rather, our enquiry is an exercise in conceptual elucidation: it aims to re-examine the concept of practice and to articulate two alternative conceptions of it. ${ }^{10}$ There has been confusion on this score in the practice turn debate. One reason for this might be that the term practice is ambiguous and captures two distinct intuitions. Aristotelians use praxis to mean action. Action here is a generic conception that covers the entire realm of doing opposed to the realm of theorising or contemplation. ${ }^{11}$ Wittgensteinians, in contrast, postulate a rule-based framework (resembling a game), which enables the agent to perform a particular action. Henceforth we shall refer to this framework as a practice (singular term), whose plural form is practices. For the generic conception of action we shall use the term practice (general term that has no singular and no plural form). Understood in those terms, Aristotle's praxis corresponds to practice, and Wittgenstein's language-game to $a$ practice. $^{12}$

But our investigation is also an exercise in philosophical analysis: achieving a coherent articulation of any putative conception demands a fair amount of reconstruction and idealisation. Hence, it is better to think of the two conceptions that we set out to investigate as Aristotelian and Wittgensteinian rather than as Aristotle's or Wittgenstein's per se. In pursuing this analysis we hope to raise some philosophical questions that elucidate the character of the international realm as a realm in which certain agencies, states, act on the basis of shared practices. In particular, we wish to bring a discussion of Wittgensteinian practices to bear on a normative theory of International Relations.

Relations: The Next Generation (Armonk: Sharpe, 2001), pp. 13-35 (pp. 17-20); Rey Koslowski und Friedrich V. Kratochwil, 'Understanding change in international politics: the Soviet Empire's demise and the international system', International Organization, 48:2 (1994), pp. 215-47; Karin M. Fierke und Antje Wiener, 'Constructing institutional interests: EU and NATO enlargement', in Thomas Christiansen et al. (eds), The Social Construction of Europe (London: Sage, 2001), pp. 121-39 (p. 124); Antje Wiener, 'The embedded acquis communautaire: Transmission belt and prism of new governance', in Karlheinz Neunreither and Antje Wiener (eds), European Integration after Amsterdam (Oxford: Oxford University Press, 2000), pp. 318-41 (pp. 323-8).

${ }^{8}$ On 'language-games' see Wittgenstein, PI, esp. $\$ \$ 23,68-86$.

${ }^{9}$ It would be impossible to list all IR scholars with interests in Aristotle and Wittgenstein, given the prominence of both philosophers. For a small, representative sample of IR theorists working in the Aristotelian tradition of praxis, see fn. 15 below. An example of a Wittgensteinian reading of IR theory is Karin M. Fierke, 'Links across the abyss: Language and logic in International Relations', International Studies Quarterly, 46:3 (2002), pp. 331-54; and Fierke, 'Wittgenstein and International Relations theory', in Cerwyn Moore and Chris Farrands (eds), International Relations Theory and Philosophy (New York: Routledge, 2010), pp. 83-94. A poststructuralist reading of ethics in IR, indebted to Wittgenstein's notion of 'grammar', is Véronique Pin-Fat, Universality, Ethics and International Relations (London: Routledge, 2009).

${ }^{10}$ Relevant here is the distinction between a concept, and specific conceptions of that concept. See Ronald Dworkin, Taking Rights Seriously (London: Duckworth, 1977), pp. 134-6.

11 Aristotle, Nicomachean Ethics, The Works of Aristotle, Vol. IX, ed. and trans. W. D. Ross (Oxford: Clarendon, 1925) hereafter abbreviated as ' $N E$ '. As per convention, references are to numbered passages. See NE 1178b20 and Aristotle, Metaphysica, The Works of Aristotle, Vol. VIII, ed. W. D. Ross (2nd edn, Oxford: Clarendon Press, 1928), a 993b 20.

${ }^{12}$ Wittgenstein himself uses the term a practice as synonymous with a language-game, for example, PI, $\$ 202$. 
The exposition has four sections. The first presents Brown's assessment of the practice turn in IR. In prioritising praxis and by showing its relevance for normative theory of International Relations, his argument prepares the ground for our own analysis. ${ }^{13}$ Because our core thesis turns on the distinction between Aristotle's praxis and Wittgenstein's language-games as alternative conceptions, the second section analyses each conception in detail. In the third section, we articulate reasons that support this distinction. The concluding pages shift the focus back to international relations to reveal the normativity of international practices. To this end, we sketch a Wittgensteinian approach to international practices that connects language-games to the older idiom of international society.

\section{The 'practice turn' in International Relations}

Brown begins his review of the practice turn in IR by noting that the concept of practice has its roots in social theory and philosophy and its assessment therefore cannot be confined to the perimeter of IR theory. In his assessment he pursues three aims. First, to elucidate the character of Aristotle's praxis. Second, to explain its affinity with Bourdieu's notion of practice. Third, to show that one strand of international political theory, classical realism, from Thucydides on to twentiethcentury realists such as George Kennan and Hans Morgenthau, points to the need for cultivating certain ethical virtues that Aristotle locates in the realm of practice. ${ }^{14}$ As a result, Brown identifies an overlap between three sets of ideas that are seldom seen as interrelated: Aristotle's praxis, Bourdieu's theory of practice, and classical realism. ${ }^{15}$

It may be helpful to outline Bourdieu's theory of practice with its three pillars: habitus, capital, and field. Habitus stands for an embodied, largely unconscious disposition to act. ${ }^{16}$ Paradigmatically it typifies the individual agent, but Bourdieu also treats the habitus as a macro property of social groups (for example, class habitus). ${ }^{17}$ Capital (as a term of art) represents a social relation established between agents as holders of resources assumed to be scarce and contested. There are various

${ }^{13}$ Brown emphasises the importance of praxis for normative international relations theory, we ask what implications follow for normative international relations theory if we move from praxis to languagegames.

14 Brown, 'The practice turn', p. 448. One valuable aspect of Brown's analysis is that it draws attention to the normative aspect of realism. (In this discussion, 'realism' designates a theory of politics and international relations, not a metaphysical or scientific doctrine.) Brown shows (p. 449) that realist Hans J. Morgenthau is not only a proponent of science, as may appear from his best-known work Politics among Nations, but also of normative analysis, particularly in Scientific Man vs. Power Politics. See Morgenthau, Politics among Nations: The Struggle for Power and Peace (New York: Alfred A. Knopf, 1948); Morgenthau, Scientific Man vs. Power Politics (Chicago: University of Chicago Press, 1946). For an argument which reveals the internal complexity of realism as an ethical and meta-ethical position see Terry Nardin, 'Realism and redistribution', The Journal of Value Inquiry, 23:3 (1989), pp. 209-25. See also Marshall Cohen, 'Moral skepticism and International Relations', Philosophy and Public Affairs, 13:4 (1984), pp. 299-346.

15 Apart from Chris Brown, IR scholars who have explored Aristotelian themes relevant to the present enquiry include, for example, Friedrich V. Kratochwil (praxis) and Richard Shapcott (phronesis). Kratochwil, 'The path of legal argument', Rules, Norms, Decisions: On the Conditions of Practical and Legal Reasoning in International Relations and Domestic Affairs (Cambridge: Cambridge University Press, 1989), ch. 8, pp. 212-48; Kratochwil, 'Making sense of international practices', in Pouliot and Adler (eds), International Practices, pp. 36-60; Richard Shapcott, Justice, Community, and Dialogue in International Relations (Cambridge: Cambridge University Press, 2001), ch. 4, pp. 130-79 (pp. 152-61). We have selected Brown's Aristotelian analysis as our point of departure because of its explicit focus on ethical considerations.

${ }^{16}$ On habitus see Bourdieu, Outline, pp. 72-3.

${ }^{17}$ On the societal aspect of habitus see Bourdieu, Outline, pp. 83-5, 97; and The Logic of Practice, p. 56. 
kinds of capital: symbolic, economic, statist, political, financial, to mention the most prominent ones. ${ }^{18}$ Finally, field is a relatively autonomous area of social space wherein contestation over capital holdings takes place. ${ }^{19}$ In modernity, the two elementary principles of social differentiation comprise cultural capital and economic capital. ${ }^{20}$ Where does the concept of practice fit in? Practice, as Bourdieu understands it, is the patterned outcome of habitual action of individuals or groups. Its proper account demands that we take into consideration the agents' capital endowments and the field(s) within which they interact.

By defining capital as a social relation, Bourdieu implies that it is not necessarily related to tangible resources or objects. IR theorists from the practice turn have seized on Bourdieu's vocabulary to combat mainstream IR theorising, which measures power and security in tangible terms that lend themselves to empirical quantification. The book, which has structured recent debates on the practice turn in IR, Pouliot's International Security in Practice (2010), presents a Bourdieu-inspired interpretation of the 'game' of post-Cold war international security with its leading players: Russia and NATO. ${ }^{21}$ NATO, Pouliot claims, is the dominant player as it commands 'cultural symbolic' capital - such as the rule of law and democracy promotion - which at present enjoys a higher currency than 'material institutional' capital based on military force. ${ }^{22}$ Military force continues to determine Russia's position in the post-Cold War field of international security just as it determined the Soviet Union's position during the Cold War.

Brown's intent is not so much to scrutinise the details of Pouliot's argument as to show that its master concept, habitus (dispositional action) is parasitic on Aristotle's hexis (state of mind, disposition). Both Aristotle and Bourdieu are occupied with the question of dispositions, yet it would be improper, as Brown correctly remarks, to classify Bourdieu as a full-blooded Aristotelian. Bourdieu associates practice with 'inarticulate, common-sense knowledge', whereas Aristotle associates it with the articulation of reasons. ${ }^{23}$ Because for Aristotle, practical reasoning involves judgement and reflection, it cannot be reduced to an unconscious, inarticulate disposition to act. The excellence - or virtue - achieved in practical reasoning is what Aristotle terms practical wisdom, phronesis. $^{24}$

Brown calls for a phronetic international political theory and contends that its 'Aristotelian moments' are discernible in the tradition of classical realism. Phronesis is a sister concept to prudence. For Aristotelians, to act phronetically is carefully to weigh the consequences of available courses of action, and for classical realists, analogously, to act prudently is to pursue action that is cautious and circumscribed. ${ }^{25}$ Either way, action falls back on practical judgment that is not amenable to scientific precision: practical deliberation is an art. ${ }^{26}$ Because the only way to master this art is by accumulating experience, the seasoned political practitioner assumes centre

${ }^{18}$ On various types of capital as structuring various fields, see chs 2 and 3 of Pierre Bourdieu, Practical Reason: On the Theory of Action (Stanford: Stanford University Press, 1998), pp. 19-30, 31-74.

19 Bourdieu, 'Structures, habitus, practices', ch. 3, pp. 52-65; 'Structures and the habitus', ch. 2, pp. 72-95. On field, see The Logic of Practice, pp. 66-8 and Outline, p. 184. A more accessible presentation of Bourdieu's triad is found in Practical Reason.

${ }^{20}$ Bourdieu, Practical Reason, p. 15.

21 See fn. 1 earlier.

22 Pouliot, International Security in Practice, pp. 148-61.

23 Brown, 'The practice turn', p. 445.

${ }^{24}$ For a definition of phronesis see $N E, 1138 \mathrm{~b}-1141 \mathrm{a}$.

25 Brown, 'The practice turn', p. 453.

${ }^{26}$ Here 'art' is taken to mean the opposite of science; it does not refer to what Aristotle would call a 'craft'. 
stage - this inter alia, sets classical realism apart from the scientific postulates of neorealism (structural realism). ${ }^{27}$

The upshot of the above argument is that classical realism is the proper form of political realism. Here the problem of politics is understood as one of contingency decision-makers at the helm of the state must act by anticipating contingencies. To be able to respond adequately to changing circumstances responsible political leaders should avoid basing their judgements on rigid devices such as rules or principles. Typically, a rule regulates a general class of actions and is a proposition laid down in advance of the action it is supposed to regulate. ${ }^{28}$ The tacit premise is that different actions count as sufficiently similar to be covered under the same rule, and that the rule must be announced before the agent begins to deliberate. Any theory that is rule-based is bound to restrict the agent's freedom of action: rules operate as action constraints. Thus, to be an effective guide within the vicissitudes of the political universe, phronetic or prudential judgement must be construed as judgment not strictly tied to the idea of rules.

Within ethical theory, the opposition between prudential ethics and rule-based ethics is a familiar one. Aristotle's ethics, together with the prudential doctrine of classical realism, is opposed to Kant's moral theory that takes rules and principles to be the foundation of the moral universe. ${ }^{29}$ As Brown himself notes, his Aristotelian argument is directed against accounts of ethical conduct that define it as action constrained by rules. ${ }^{30}$ This stance implies that practice should be viewed as something prior to theory. Theoretical reflection matters, the claim goes, but it consists of generalisations distilled from the realm of practice and not in an independent theoretical realm against which practice may be assessed. This claim vitiates Kant's idea of pure practical reason, which postulates purely theoretical (a priori) principles of action to guide the deliberating agent. ${ }^{31}$

Brown's analysis is cogent and illuminating, but it advises students of international relations to look up to a single conception of practice: praxis. It entails rule-agnosticism, if not an outright rule-scepticism. This agnosticism rests on a particular, Kantian understanding of rules as formal principles. There is, though, a different, more complex, understanding of rules, which leads to an alternative account of social practices. We are referring to Wittgenstein's account of language-games as outlined in his Philosophical Investigations. In this late work, he contends that the activity of rule-following, rather than rules per se, is constitutive of language-games, or 'practices' in our terms. ${ }^{32}$ On this practices-centred conception rules not only constrain, but constitute action. In the remainder of this discussion, we argue that this conception affords us a finer-grained understanding of practices, including international practices, than that offered by Aristotle's praxis. To make good on this claim, in the next section we undertake a closer examination of these two contending conceptions, and of a telling criticism of praxis by James Urmson. ${ }^{33}$

27 The core text of structural realism (neorealism) is Kenneth Waltz, Theory of International Politics (Boston, MA: McGraw Hill, 1979).

28 These are just the minimum two conditions necessary to identify a rule - see, for example, H. L. A. Hart, The Concept of Law (Oxford: Clarendon Press, 1961), pp. 21-3. An insightful discussion of rules within games, rules of thumb, and other kinds of rules is Joseph Raz, Practical Reason and Norms (London: Hutchinson, 1975).

29 Immanuel Kant, Groundwork of the Metaphysics of Morals, ed. Mary Gregor (Cambridge: Cambridge University Press, 1997). References are to volume and page number of the Prussian edition of Kant's works.

30 Brown, 'The practice turn', p. 448.

${ }^{31}$ Kant, Groundwork, G 4:390, 4:420.

32 See fn. 8 earlier.

33 J. O. Urmson, 'A fallacy of Aristotle's about ends', Argumentation, 9 (1995), pp. 523-30 (p. 523 ). 
Aristotle on praxis and Wittgenstein on language-games

\section{Aristotle on praxis}

Aristotle's account of praxis is primarily contained in the Nicomachean Ethics. ${ }^{34}$ For Aristotle, ethics involves an inquiry into the good life. To enjoy the good life, eudaemonia, is 'to live well and to fare well' - or to flourish as a human being. One notable feature of Aristotle's ethics is its concern with ends. Aristotle asks what sort of ends, when pursued and achieved, would make a person eudaemon? Possessing certain external goods such as a pleasing appearance, money, and friends, are required, but what matters the most are internal goods, 'the goods of the soul', consisting in the pursuit of certain actions. ${ }^{35}$ What complicates matters is that Aristotle employs two notions of action that differ in scope. Praxis, as we have been discussing the term so far, designates action in a general sense, as when action is opposed to thinking or theorising. In the restricted sense, praxis designates one type of action performed on a particular occasion, as a dated episode; but as we shall see in a moment, there are two such subtypes of datable action.

Aristotle writes in the opening paragraph of the Nicomachean Ethics:

Every art and every inquiry, and similarly, every action and pursuit, is thought to aim at some good; and for this reason the good has rightly been declared to be that at which all things aim. But a certain difference is found among ends; some are activities, others are products apart from the activities that produce them. ${ }^{36}$

Aristotle is making two claims: (1) that the good consists in the pursuit of ends; and (2) that the ends most worthy of pursuit are those actions he calls praxis ('activities') as opposed to poiesis ('productions'). Praxis in the restricted sense ('activity') and poiesis ('production') both exemplify a kind of action (action in the restricted sense). Unlike action in the general sense, any action in the restricted sense is performed on a particular occasion as a dated episode. ${ }^{37}$ An 'activity' is by definition complete in itself. ${ }^{38}$ In contrast, a 'production' aims at some external end - a product. ${ }^{39}$ Thinking, seeing, and playing a flute exemplify activities; building, practicing medicine, and engaging in strategy are productions. ${ }^{40}$ The product of building is a house; that of medicine, health; and that of strategy, victory. In contemporary terms we might say that productions are those actions carried out for instrumental reasons.

It is interesting to consider how this Aristotelian typology of actions might be applied to the world of international relations as it is familiar to us. There are many actions in international affairs that may be understood in instrumental terms, as 'productions' in Aristotle's language: negotiating the establishment of an international cyber network of one kind or another; working towards the establishment of a world-wide air traffic control system; making the military equipment of allies compatible with one another, and so on. Examples of Aristotelian

${ }^{34}$ Aristotle, NE.

$35 \mathrm{NE}, 1098 \mathrm{~b} 15$.

$36 \mathrm{NE}, 1094 \mathrm{a}$.

${ }^{37}$ Unless otherwise specified, henceforth praxis shall refer to praxis in the general sense of action as such.

38 An activity is complete at any point instant, whereas a production has a terminus - it will have been completed at some future point instant. Urmson, 'A fallacy of Aristotle's about ends', p. 525. On praxis in the restricted which designates an 'activity' as complete in itself see Terence Irwin, Nichomachean Ethics (Indianapolis: Hackett, 1985), p. 385.

${ }^{39} N E, 1139 \mathrm{~b}$ and $N E, 1140 \mathrm{a} 5-\mathrm{a} 10$.

${ }^{40} N E, 1097 \mathrm{a} 15-\mathrm{a} 20$. 
'activities' might include the organisation of the Olympic Games; the putting on of World Cup Football tournaments; and the running of global literary or music festivals. Presumably these count as activities because most people would regard them as worthwhile in themselves rather than as a means towards bringing about some other ends.

Aristotle also distinguishes praxis from theoria, an activity of contemplation that is complete in itself. ${ }^{41}$ But whereas theoretical knowledge studies universals, truths that are immutable and 'cannot be otherwise', practical knowledge deals with particulars that an agent could change at will, by acting. Practical knowledge, as noted, attains its excellence in phronesis. To have mastered the virtue of phronesis is to be in a position to choose well - that is, to act so as to bring about a wished-for end (a good) in a world of particulars.

From a number of difficulties that confront Aristotle's doctrine of action, two should be mentioned. First, Aristotle holds that activities cannot simultaneously be productions, and that the good life consists in the pursuit of activities. As he asserts, life is praxis, not poiesis. ${ }^{42}$ Aristotle scholars have found this proposition problematic. John Ackrill has pointed out that it is not obvious that praxis and poiesis are mutually exclusive. He asks us to consider an example: repaying a debt is an activity, and mending a fence is a production, but I can repay a debt to my neighbour by mending his fence. ${ }^{43}$ This seems to undermine the original praxis-poiesis distinction. A more serious difficulty has been identified by Urmson who charges Aristotle with a failure to distinguish internal from external ends of action. ${ }^{44}$ We now turn to Urmson's position as it supplies a plausible account for the (non-trivial) difference between Aristotle's and Wittgenstein's views of particular action.

Aristotle holds that the test to establish whether a particular action is an activity (praxis in the narrow sense) is whether or not it has an end outside of itself. If no such ends are detectable, then the action is an 'activity'; otherwise, it is a 'production'. But this way of classifying actions, Urmson claims, does not work because one and the same action lends itself to conflicting descriptions: some of its descriptions would refer to internal ends (roughly, non-instrumental ends), while some others would refer to external ends (instrumental ends). ${ }^{45}$ Consider an action $A$ that might be performed for the sake of $\mathrm{x}$, or for the sake of $\mathrm{y}$, or for the sake of $\mathrm{z}$, where $\mathrm{x}, \mathrm{y}, \mathrm{z}$ each designates an end, be it external or internal. For example, John may be playing a flute as an end in itself (internal end), or he may be playing it in order to pass a musical examination (external end), or he may be playing to make money (another external end). Urmson concludes that Aristotle's view of action exhibits a fallacy - what Aristotle has failed to notice is that an activity can always be made to have external ends; and conversely, that having an external end does not imply that the action necessarily lacks an internal end.

Nonetheless, it is important to move beyond Urmson's diagnosis. We can identify a more general shortcoming of Aristotle's position. Aristotle, as we may recall, assumes that the unit of analysis is action in the restricted sense. Action so construed, which may be an 'activity' or 'production', is particularised: it is performed on a

${ }^{41}$ NE, 1178b20 and Aristotle, Metaphysica, a 993b 20.

42 Aristotle, Politics, The Works of Aristotle, Vol. X, ed. W. D. Ross, trans. Benjamin Jowett (Oxford: Clarendon Press, 1921), 1254a5.

43 John L. Ackrill, ‘Aristotle on action', Mind, 87:348 (1978), pp. 596-601 (p. 596).

${ }^{44}$ See fn. 33.

45 Urmson, 'A fallacy of Aristotle's about ends', pp. 524, 526. 
particular occasion, indexed to a particular segment in time and space. A further assumption that Aristotle makes is that a typical action is an individual-level action, carried out by a single designated agent (which might be an individual or a collective actor such as a state). But imagine that we wish to investigate the relations between agents, a concern focal to the study of International Relations. Then we would be entering an altogether different domain of inquiry, not individual level-action but social action. (For to speak of society is to think of individuals standing in certain relations to one another). ${ }^{46}$ Aristotle's premises, as we shall show, cannot accommodate the social aspect of individual-level action. The analysis of social action that we put forward in what follows is an invitation to consider individual actions in the contexts of the social practices (language-games) in which they take place, including international practices.

\section{The problem of social action}

The thrust of our argument is that individual-level, dated actions performed by participants in international relations can only be understood in the context of the global practices in which they are carried out. The actions that are likely to attract the interest of those who seek to understand international relations might include some of the following: going to war, signing an international treaty, the mass migration of people across international borders, setting up of international organisations, secessionist movements struggling for national self-determination, and so on. Before looking into the causes of such actions or the reasons people may have for performing them, an investigator (an observer) would need to understand what has been done, by determining whether what the actor under investigation was doing, was, indeed, an instance of let us say, treaty making, rather than an instance of signing a commercial contract. Another way of putting this point is that the investigator, in every case, must be able to comprehend the meaning of the action observed, which is distinct from an observation of the actor's physical movements. Contrast writing a letter (action) with putting marks down on paper (physical movement).

The problems encountered in understanding action are analogous to those encountered when trying to understand utterances or sentences in a language. ${ }^{47}$ For example, before an investigator can start asking questions about why someone swore allegiance to the Queen, he or she has to understand what the sounds uttered in saying: 'I, Joan Smith, do swear that I will be faithful and bear true allegiance to Her Majesty Queen Elizabeth' mean. Making sense of Joan Smith's utterance is conditional on knowing the meaning of its words, both as separate lexical units and as components of a whole sentence. Only those who already possess sufficient understanding of the relevant language would be able to decipher the meanings of such expressions. In the above case, to determine that the action observed is swearing

${ }^{46}$ The idea is sometimes expressed in juridical terms as ubi societas ibi ius ('where there is law, there is society'). But we may interpret 'law' more loosely, to refer to rules as social relations. To this rule-based tradition belong thinkers such as Hugo Grotius, Thomas Hobbes, and more recently, John Rawls. Grotius, 'Preliminary discourse', in Richard Tuck (ed.), The Rights of War and Peace [De Iure Belli ac Pacis], 3 vols, rev. of 1738 Barbeyrac's translation (Indianapolis: Liberty Fund, 2005), esp. §8; Hobbes, Leviathan, ed. C. B. MacPherson (London: Penguin, 1968 [orig. pub. 1651]); and John Rawls, A Theory of Justice (Cambridge, MA: Belknap University Press, 1971).

${ }^{47}$ Here 'language' includes natural language as well as specialised language (such as mathematics or physics) but excludes what logicians call an 'ideal language' that is purely syntactical. 
an oath and not (say) reciting a poem, the investigator must have learned (to some degree at least) how an oath of allegiance is sworn within the context of English law. The learning required here is both holist and social, it is not private.

\section{Wittgenstein on language-games}

One of the notable insights of Wittgenstein's perspective is its holism. It is a holist standpoint insofar as the meaning of an action (for example, swearing an oath) can only be understood within the context of the whole, in this case, the language-game, in which it is nested. ${ }^{48}$ Crucial to this way of understanding action (including all the actions of speakers using a language) is the claim that the criteria specifying what counts as a successful performance of an action are isomorphic to criteria that establish correct use within a given language - the default premise is that a critical mass of language speakers are competent in the sense that they already know, or indeed understand, these criteria.

This is a difficult point that needs some elaborating. Wittgenstein takes language, as a meaningful structure, to be the prototype of human practices - this is why practices bear the label language-games. But, correlatively, practices are languagegames. In this sense, language is not a pile of dead rules, ossified in grammar books, but a living practice (akin to a game) carried out within a linguistic community of language users. For a language so construed, meaning is 'meaning in use'. ${ }^{49}$ A curious notion that elucidates the connection between the language aspect and the game aspect of language-games is rule-following. To follow a rule is to know when in making an utterance, or in performing an action, a mistake has been made. ${ }^{50}$ What Wittgenstein in effect is saying is that in learning how to participate in a language-game one is learning to follow a rule: an activity that demands differentiation between successful performances and mistakes. But Wittgenstein rejects any suggestion that rule-following is a two-step procedure in which, an actor supposedly first learns a rule (from a rule book, for example), and then, in a second phase, applies it by acting in accordance with that rule. Instead, the notion of rule-following highlights the idea that when a teacher shows a novice how to follow a rule, by articulating what would count as making a mistake, this articulation is

48 Wittgenstein, PI, $\$ 43$.

49 Roughly, the idea of 'meaning in use' is that each basic rule of a language - which specifies what something means within the universe of discourse constituted by that language - and the application of this rule by a language-user do not comprise two consecutive actions but one single action, as we shall explain in more detail in the next paragraph. In the Philosophical Investigations, Wittgenstein recanted his earlier logical atomism expounded in the Tractatus Logico-Philosophicus (New York: Routledge, 1961 [orig. pub. 1921]). He rejected similar claims that had been made by analytic philosophers such as his mentor Bertrand Russell, and later, Moritz Schlick and Rudolf Carnap, who thought it was possible to establish satisfaction criteria (typically, truth-functional) to determine what features a proposition in the language of observation would have to have if it was to be counted as meaningful. In contrast, Wittgenstein's theory of meaning in use supposes that no independent language of observation is necessary to determine instances of correct language use ('Language is in order as it is', PI, §98). Participants in language-games are not called upon to find a scientific theory or a philosophical one to inform them of the correctness of their performances. They are taught how to distinguish correct from incorrect performances within the relevant language-game by other, more competent participants in that game. A similar argument for meaning in use was developed independently, and in terms of a different vocabulary, by Michael Oakeshott in On Human Conduct (Oxford: Clarendon Press, 1975).

50 This is Peter Winch's definition of rule-following, derived from Wittgenstein. Winch, The Idea of a Social Science and Its Relation to Philosophy (London: Routledge, 1958), p. 32. For a general discussion on this topic see Alexander Miller and Crispin Wright (eds), Rule-Following and Meaning (Chesham: Acumen, 2002). 
already an instance of correctly using ('applying') the rule. In discussing how a pupil is initiated into a new language-game, Wittgenstein writes:

I shall teach him to use the words by means of examples and by practice. - And when I do this I do not communicate less to him than I know myself.

In the course of this teaching I shall shew him the same colours, the same lengths, and the same shapes, I shall make him find them and produce them, and so on. I shall, for instance, get him to continue an ornamental pattern uniformly when told to do so. - And also to continue progressions. And so, for example, when given: . . . . to go on: . . . . . . . . . .

I do it, he does it after me: I influence him by expressions of agreement, rejection, expectation, encouragement. I let him go his way, or hold him back; and so on. ${ }^{51}$

In this passage, Wittgenstein contends that the novice is being taught, not by laying down explicit rules or abstract formulations, but by showing him or her how specific rules are being used to perform this or that action. ${ }^{52}$ Of course, this activity of teaching and learning is one specific practice that takes place against the background of the other practices that may be common to the teacher and the pupil.

\section{Why are language-games distinct from praxis?}

We propose to translate these Wittgensteinian insights into an analytical platform for understanding social action that would enable us to make better sense of the actions of international actors. Our starting premise is that social action is, at base, normatively constituted action. This means that in learning how to carry out specific actions, the individual agent is required to take into consideration the intelligent responses of other agents in the practice. Within the context of a practice, in deliberating about what to do, I am required to consider what other participants have done and what I ought to do in response. For example, in playing a chess match I have to keep in mind the following norm: A player ought to keep an eye out for a move by the opponent that would lead to the capture of the King and to respond in ways that would forestall this. In many, if not all social practices, learning how to act requires mastering a great number of rules. The general feature of such rules is that they are 'action-guiding' (normative) considerations. ${ }^{53}$

The intuition here is that understanding social action demands a different unit of analysis to that employed for the examination of individual, non-social action. Social action like all action implies shared meanings. But it implies, further, the presence of meaningful social standards - rules - that govern the actions of a number of individuals, and transform these individuals into participants in a shared practice. To qualify as social standards the rules must be upheld in common - a practice would not exist were each individual to follow his or her private rules of conduct. ${ }^{54} A$ practice (Wittgenstein's language-game) is a rule-based framework enabling each participant to act on a particular occasion. The premise is that the agent acts within the framework.

${ }^{51}$ Wittgenstein, $P I$, $\$ 208$; emphasis in the original.

52 This reflects the later Wittgenstein's understanding that philosophers committed to ideal language and truth-functional semantics had misunderstood the relation between language and reality. They had been bewitched by certain pseudo problems which can be cleared if they would turn to studying how language is actually used within various language-games. ('Philosophy is a battle against the bewitchment of our intelligence by means of language.' PI, §109).

${ }^{53}$ R. M. Hare, The Language of Morals (Oxford: Clarendon Press, 1952), pp. 1, 29-30.

54 As Wittgenstein says 'obeying a rule is $a$ practice ... hence it is not possible to obey a rule privately', PI, $\S 202$. 
This indicates that one must know the constitutive rules of the practice in order to perform the requisite action. On Wittgenstein's view, the particular action the individual performs has the character of social action because it is constituted by social rules. A practice in effect integrates the concept of social rules within the definition of individual-level action. This is in contrast with Aristotle's concept of individual-level action, which does not invoke a background of rules. In one case we have action simpliciter (Aristotle), in the other, socially (or publically) rule-governed action (Wittgenstein). In what relation, then, does Aristotle's general concept of praxis stand to Wittgenstein's framework of action or language-game? We may think of a language-game as one concrete domain of action, parsed off from the general domain of action (praxis in the broad sense), and held together by the fact that its participants subscribe to common rules. One putative definition of a practice is 'a public system of rules which specify rights, duties and roles' for a social group. ${ }^{55}$ In this category fall institutions such as the political state but also conventions, rites, and games such as football and chess.

Let us now consider whether Aristotle's notion of action in the restricted sense (which may be activity or production) to see whether it differs, in some significant way, from an action that falls within a social practice. This brings us back to Urmson's analysis of internal and external ends. One of its corollaries, which demands special attention, is that Aristotle regards an activity as reflexively identical with itself, as in the schema $\mathrm{A}$ is $\mathrm{A}$. The internal end of playing a flute is to play a flute. A contemporary example would be that the internal end of buying coffee is to buy coffee. The activity refers back to itself - its self-referentiality constitutes its internal end. However, an action embedded within a practice or language-game has a principally different structure. An action so embedded has internal ends that are not determined self-referentially, but determined on a scale up - by the internal ends of the language-game to which the action under consideration belongs. ${ }^{56}$ On this view, buying coffee has to be understood within the social practice of the market. But the point is a general one. A practice (language-game) is a domain whose internal ends are specified by the practice-defining rules: these are constitutive rules. ${ }^{57}$ Because rules embody normative requirements, an action cannot be self-legitimising, but must be legitimised by the pre-existing rules that constitute the practice in question. The logical relation that obtains here is not one between an action and itself (its internal end), as it was for Aristotle, but between an action and the rules of the relevant practice. To act, on the practice-centred conception, is to follow the social rules of a practice: rule-following is at once the logical and normative basis of practices.

Wittgenstein's philosophy of language-games, no less than Aristotle's praxis, has its critics. But its principle value is that it recognises the irreducible plurality of practices: war waging, university teaching, citizens participating in the institutions of government - all these represent domains of rule-following that have a high degree of internal consistency. The internal logic of each individual practice is disclosed by a

${ }^{55}$ Naomi Kasher, 'Deontology and Kant', Revue Internationale de Philosophie, 32: 124(4) (1978), pp. 551-8 (p. 553).

${ }^{56}$ Kasher ('Deontology and Kant') develops the idea of internal ends, which is also key to our argument. But there are two principal differences. Kasher assumes: (i) that a practice conception can be attributed to Kant; and (ii) that the concept of an internal end is a substitute for the concept of constitutive rules. We reject both (i) and (ii).

${ }^{57}$ A constitutive rule stipulates that ' $x$ counts as $y$ in context C'. John Searle, Speech Acts: An Essay in the Philosophy of Language (Cambridge: Cambridge University Press, 1969), p. 35. 
set of internal ends stipulated by concrete practice-defining rules. And although it is not impossible to transport conclusions across different practice domains, doing so would generate confusion and incoherence. Consider two games, boxing and chess, whose ends appear identical, winning over an opponent. This appearance turns out to be deceptive once we examine the relation between rules and internal ends within each game. The internal end of boxing is winning, defined by rules such as knock-out or victory on points. The internal end of chess is winning, defined by different rules - check-mate or stale-mate (prohibiting the repetition of three identical configurations of moves on the chess board). It would be pointless to look for some common essence called 'winning' in these two games since they exhibit differentia in a strong sense - they are not merely different, but distinctive domains. In sum, each language-game constitutes a distinctive domain of action constituted by social rules, rules which supply criteria for interpreting the domain as a whole together with its internal ends, and therefore for interpreting the players' actions as matching or deviating from these ends.

It would be hard, perhaps impossible, to imagine an actual human practice that is exhausted by one solitary rule. ${ }^{58}$ Human practices - conventions, games, institutions such as law and morality - cannot accommodate such rule monism. We may say that a practice always contains a relatively large number of rules that hang together. Practices are not marked out by the mere presence of rules, but by clusters of rules forming more or less coherent constellations. Moreover, it is requisite that we, thinking and choosing human beings, are able simultaneously to participate in more than one practice at a time. Unless this condition of simultaneous participation is met, we would have no vantage point for discriminating between practices. This approach of meaning differentiation, which asks questions about the meaning of practice $\mathrm{P} 1$, as differentiated from practice $\mathrm{P} 2$, practice $\mathrm{P} 3$, and so on, is the sole route for telling practices apart. To generalise, to know what constitutes a practice is to know the meaning of its constitutive rules as differentiated from the meaning of the constitutive rules of other practices.

\section{International practices from a Wittgensteinian point of view}

We now proceed to sketch the contours of a Wittgensteinian approach to international practices. In particular, we propose to connect Wittgenstein's conception of practices as language-games to the assumptions of an older theory of international society, originally propounded by Hugo Grotius. ${ }^{59}$ Its perhaps best-known contemporary exponent, Hedley Bull, defines international society as 'a group of states conscious of certain common interests and values ... [which] conceive themselves to be bound by a common set of rules in their relations with one another, and to share in the workings of common institutions ${ }^{90}$ - the balance of power, international law, war, and diplomacy. Bull clearly identifies international institutions with rules, in the sense that the core institutions of international society count as constitutive rules that determine

${ }^{58}$ Raz, Practical Reason and Norms, p. 114.

59 Grotius, The Rights of War and Peace, Vol. I.

${ }^{60}$ Hedley Bull, The Anarchical Society: A Study of Order in World Politics (3rd edn, Houndsmill: Palgrave, 2002), p. 13. Our argument points to alternative conceptions of international society, of which Bull's is just one well-known example. We are interested in outlining the ethical dimensions of such conceptions. See David R. Mapel and Terry Nardin (eds), International Society: Diverse Ethical Perspectives (Princeton: Princeton University Press, 1998). 
the identity of its participants (states). What is not so clear is whether he regards these international institutions as having the status of formal institutions, informal practices or some other rule-bound arrangement. But the basic idea of an international society could be developed in a Kantian, an Hegelian, or a Wittgensteinian direction. What is not a feasible option is to wed it to the Aristotelian conception of praxis, since this conception would relegate rules to auxiliary concerns.

Consider a Kantian interpretation of the institutions of international society. It would single out international law as the foundational institution and would impose a limit on what 'law' means - namely, a 'moral' institution, where morality articulates principles of conduct accessible to all men and women by virtue of their rational nature. ${ }^{61}$ For Kant, moral is the converse of both instrumental and prudential. And if Kantian morality is taken to be the guiding standard of conduct, ex hypothesi the rival standard, phronesis or prudence, would have to be shelved and together with it, phronetic international political theory that Brown associated with classical realism. An international political theory along strict Kantian lines would oblige us to accept the claim that international law (understood non-instrumentally and non-prudentially) is the fundament of the international realm. It is apposite to speak of the fundament since Kant's perspective is rule-monist: either we have law, or we have a condition of lawlessness, chaos, and violence (a Hobbesian 'state of nature'). $^{62}$

But it is possible to approach the distinction between Kantian morality and prudence from a different angle. Terry Nardin has argued there are two separate versions of prudence, and thus two kinds of political realism: 'moral realism' and 'prudential realism'. ${ }^{63}$ Moral realists treat prudence as a moral criterion - here the ends justify the means. For prudential realists however, prudence is a standard of action that lies outside the purview of morality and ethics. The logic of prudential conduct is expediency: it may be unethical to follow it, but it gets the job done - this might be crucial in cases of 'supreme emergency' when a nation faces immanent destruction, as suggested by Michael Walzer. ${ }^{64}$ Before we inquire whether such prudential considerations fit within the recommended practices conception of international society, we have to return for a moment to the problem of rule monism, as it has bearing on the question of what a practice is.

We mentioned that a practice resists monistic compression into a single rule or principle. Each practice is an untidy, somewhat lose constellation of a multiplicity of rules, which has sufficient coherence to enable its participants to go on. But since practices differ in scope and comprehensiveness, they may overlap - so it is possible to have a constellation of practices. When several language-games coalesce into a global

${ }^{61}$ The earliest text containing Kant's moral theory is the Groundwork (see fn. 29). Kant's legal theory is presented in the Doctrine of Right, which is Part I of Kant's Metaphysics of Morals. There, Kant postulates principles of right (Recht). But even though right is supposed to delimit the agent's external freedom via coercion, coercion ought to be morally justified. Immanuel Kant, 'The doctrine of right, Part I of the metaphysics of morals', Practical Philosophy, trans and ed. Mary Gregor (Cambridge: Cambridge University Press, 1996). See also Arthur Ripstein, Force and Freedom: Kant's Legal and Political Philosophy (Cambridge, MA: Harvard University Press, 2009); and Fernando R. Tesón, 'The Kantian theory of international law', Columbia Law Review, 92:1 (1992), pp. 53-102.

${ }^{62}$ Hobbes, Leviathan, ch. 13, pp. 183-8 (pp. 185-6).

${ }^{63}$ Nardin, 'Realism and redistribution'. Nardin distinguishes (pp. 212-14) 'moral realism' (where prudence is a rival standard to morality) from 'prudential realism' (where prudence is a parallel standard to morality).

${ }^{64}$ Michael Walzer, Just and Unjust Wars: A Philosophical Argument with Historical Illustrations (2nd edn, New York: Basic Books, 1977), ch. 16, pp. 225-86. 
language-game, the result is what Wittgenstein calls a 'form of life' - a term he might have borrowed from Hegel. ${ }^{65}$ Like any other practice, a form of life exists for as long as the majority of its participants accept it. Such acceptance has a normative ring: it is an expression of shared values, not of shared opinions or preferences. ${ }^{66}$ The metaphor of a form of life which Hegel and Wittgenstein seem to share reveals that a practice is constituted as meaningful whole whose parts - rules, ends, meanings, usages - can be taken apart only as an analytical exercise. We claim that it is profitable to think of international society as a practice that is 'global', not in the geographical sense, but in the form-of-life sense.

A view of international society that bears the imprint of a Hegelian meaningful whole has been presented by Walzer in his widely acclaimed book, Just and Unjust Wars (1977). ${ }^{67}$ Because traces of prudential realism are included in what at bottom is a normative framework, it is important to understand how the presence of such realist elements affects the social conception of rule-following presupposed by such a framework. Walzer contends that the rules of international law and international morality stipulate limits on what states are permitted to do as actors in good standing in international society. In a Hegelian vein, Walzer locates the ultimate source of value within actual political communities, and the rights (of life, liberty, and community) held by their citizens. Wars inside international society thus must be just wars, subject to the constraining rules of justice. It is permissible to deploy prudential considerations when acting on the international scene - but only at the limit: when aggressors threaten to annihilate the common way of life of a political community, as it happens in 'supreme emergency'. Although the emergentist element in Walzer's account may be controversial, its objective is not to justify emergency logic, but rather to articulate its normative limits. ${ }^{68}$ Walzer's account shows that any international relations theory that takes the notion of practices seriously is spoken in the language of ethical considerations, norms, and rules. Such ethical considerations may accommodate prudential elements (for example, prudential realism), but they cannot allow prudence to become the overarching standard of conduct. The idiom of prudence belongs to a different language, that of consequences - which in a sense is also the language of Aristotle's ends - and which questions the priority of rules: both the idea that rules constrain conduct (which many see as defining of ethics and morality) and the idea that rules constitute conduct (which, as we have argued, is central to the notion of practices).

We are now in a position to appreciate the significance of the distinction between an Aristotelian, phronetic theory of international practice and a Wittgensteinian theory of international practices. The analytical focus of the former lies on the conduct of international political elite, and not on the rules of international society. One standard explanation for this difference in emphasis is that according to Aristotle political conduct is not a matter of actors blindly following rules, but of wise people (leaders) making appropriate judgements about what to do in the face of changing

${ }^{65}$ Wittgenstein's 'form of life', PI, $\$ 241$ resembles Hegel concept of 'ethical life', Sittlichkeit. See G. F. W. Hegel, Hegel's Philosophy of Right, trans. T. M. Knox (Oxford: Oxford University Press, 1981), Part III. $\S \$ 142-360$.

${ }^{66}$ Wittgenstein PI, §241: '[human beings] agree in the language they use. That is not agreement in opinions but in form of life.'

67 See fn. 64.

${ }^{68}$ This emphasis on limits distinguishes Walzer's emergentist position from that of Giorgio Agamben. See Agamben, State of Exception, trans. Kevin Attell (Chicago: University of Chicago Press, 2005), esp. pp. 6-7, 9 . 
circumstances. But expressing the contrast in these terms may create the impression that rules and judgements are separate things, whereas, if we accept Wittgenstein's view, social rules matter not as abstract propositions but as an ongoing activity of rule-following: such activity implies judgement. ${ }^{69}$ Construing the problem as rules versus judgement also oversimplifies Aristotle's position, which is not that rules should be dismissed tout court, but that whenever the judgement of wise people clashes with the rules, the latter should be sacrificed.

A better way to flesh out the contrast between the Aristotelian and Wittgensteinian conception of practices, as we have argued, is via the concept of internal ends. To say that international society is $a$ practice (language-game) is to claim that the actions of its members, states, are not determined by pre-established ends - be they national security, world domination, wealth, or survival - but by certain global social rules, which impose conditions on how, and indeed how far, any such ends may be pursued. Only those ends that are antecedently constrained by concrete practice-defining rules count as internal ends, on the Wittgensteinian interpretation that we have presented. On this interpretation, the internal ends of international society as a practice are specified by its own practice-defining rules. International society, then, is a realm of action as well as a realm of shared meanings that can be interpreted, understood, and of course, also misunderstood. Thus, the rules of the balance of power impose the condition that states should cooperate to thwart the rise of a hegemon; the rules of war, that wars should be delimited in destruction and duration; the rules of diplomacy, that the will to restore peace should be preserved and communicated in order to bring hostilities to a lasting end; and the rules of international law, that treaties should be kept, and that the persons of diplomats should be protected from grave harm even during the actual conduct of hostilities so that the restoration of international social life is not rendered impossible.

\section{Conclusion}

In the foregoing pages we put forward the argument that there are two distinct conceptions - Aristotle's praxis and Wittgenstein's language-games - which translate into two distinctive ways of understanding international affairs. Even though we favour Wittgenstein's perspective of language-games, our aim was not to repudiate Aristotle's conception of praxis, but to differentiate it from a worthy alternative. The key implication of this analysis is that it elucidates a long-standing problem in the philosophy of action pertaining to the relation between ends and rules. As we saw, Aristotle usefully pointed out that agents always act with some end in view, and Wittgenstein, that certain (even though not all) ends of action are intelligible as 'parts' embedded within social 'wholes' or language-games (practices), where each practice is constituted as a more or less autonomous system of rules. Understanding why a given agent acted in this, rather than that, manner, according to Wittgenstein, requires that we first understand the rules of the relevant social practice. To commence our investigation otherwise, say by searching for ends that supposedly represent the intrinsic properties of a given action would be to commit 'Aristotle's fallacy' which, as Urmson showed, fallaciously identifies an action with its ends.

We refined Urmson's analysis of internal and external ends, and argued that the concept of internal ends enables us to explain why there is a non-trivial difference

${ }^{69}$ As Wittgenstein explicitly notes in $P I, \S 242$. 
between Aristotle's praxis and Wittgenstein's language-games. For Aristotle, internal ends designate the performance of a particular action itself. For Wittgenstein, a particular action is part of a broader practice and thus its internal ends are determined by the internal ends of that practice. To pinpoint an Aristotelian action (praxis in the restricted sense) it suffices to pick an adequate description of its internal ends; that is, of the action itself. But it would be futile to attempt to identify $a$ practice by listing the ends its participants intend to pursue. The ends are important, to be sure, but they become significant insofar as they fit into the structure of the practice, as a meaningful whole. It is this international whole and the meanings created within it that ought to be the primary focus of research for scholars in International Relations. 